\title{
The Effect of Sustainability as Innovation Objectives on Innovation Efficiency
}

\author{
Jaeho Shin ${ }^{1,+(1)}$, Changhee Kim ${ }^{2,+(1)}$ and Hongsuk Yang ${ }^{1, *}$ \\ 1 College of Business Administration, Seoul National University, Seoul 08826, Korea; tozenith@snu.ac.kr \\ 2 College of Business Administration, Incheon National University, Incheon 22012, Korea; ckim@inu.ac.kr \\ * Correspondence: hongsuk@snu.ac.kr; Tel.: +82-2-880-2598 \\ + These authors contributed equally to this work.
}

Received: 21 May 2018; Accepted: 9 June 2018; Published: 12 June 2018

\begin{abstract}
Though sustainability exists as major objective of pursuing innovation, the effect of it on innovation performance is still unanswered. While the outcome of innovation should consider both input and output, moreover, studies on sustainable innovation are yet to consider the overall efficiency, but rather the performance itself. To fill the gap between the effect of sustainability as the objective of innovation and its innovation performance, and to bridge the hole between the outcome of sustainable innovation and its efficiency, we analyze the relationship between sustainability as innovation objective and innovation efficiency. We use 441 manufacturing companies in Korea from 2016 KIS data, and perform the data envelopment analysis (DEA) method to calculate efficiency score of each firm and tobit regression analysis to investigate the effect of sustainability as an objective of innovation on innovation efficiency. The results show that the objective of 'environmental improvement' negatively affects innovation efficiency, while 'safety improvement' positively affects the efficiency. On the contrary, the effect of 'material and energy reduction' as an objective of innovation on innovation efficiency is not verified. The implications, limitations, and guidelines for future research are presented.
\end{abstract}

Keywords: objective of innovation; sustainable innovation; innovation efficiency; data envelopment analysis (DEA); tobit regression analysis

\section{Introduction}

Lundvall (1992) mentioned that "almost all innovations reflect already existing knowledge, combined in new ways", and Johannessen et al. (1999) said that "innovation research is a fundamental study of change processes, knowledge development and knowledge integration, for the purpose of generating new combinations" [1,2]. Overall, innovation should not be regarded as a single event, but rather as a continuous and cumulative process [3]. As innovation is a core capability for sustainable companies, 'innovation' and 'sustainability' are inextricably linked [4].

Though objectives of innovation influence on innovation performance, studies on the effect of innovation goals on innovation performance are mostly limited to economic-related objectives $[5,6]$. That is, while environmental and societal reasons are the major purposes of firms pursuing innovation, the effect of sustainability as an objective of performing innovation on innovation performance is still unanswered [7-9]. In this paper, we limit our scope to sustainability-related objective only and investigate into the effect of such objective on actual innovation outcome.

As innovation is not a linear process in which inputs automatically transform into outputs, innovation performance should not be measured as performance, but rather as efficiency, including its input and output altogether $[10,11]$. Although studies that are related to innovation performance constantly measure innovation efficiency, when it comes to sustainable innovation, innovation input is 
not considered, but the output itself is measured. Therefore, we measure innovation efficiency instead of innovation performance in this paper.

To sum up, we investigate the relationship between sustainability as the objective of innovation and innovation efficiency. The sustainability-related objective of innovation could include three aspects; to reduce raw material or energy cost, to improve negative influence on the environment, and to enhance workplace environment or safety for workers. With applying the data envelopment analysis (DEA) method to find out the efficiency of innovation, we adopt three sustainability-related objectives as environmental variables and investigate the potential effect of them on innovation efficiency by tobit regression. We use 441 Korean manufacturing companies from 2016 KIS (Korean innovation survey) data and perform empirical analysis, as the data contains overall innovation data including objectives of innovation, resources used for innovation (input of innovation), and innovation performance (output of innovation).

The research is presented as follows: Section 2 explains the theoretical background, followed by Section 3, which outlines the details of the data and research method. Then, the results are given in Section 4, and finally, Section 5 elaborates the implications, limitations, and suggestions for future research.

\section{Theoretical Background}

\subsection{Sustainability as Objective of Innovation}

Innovation has been studied for long decades, and literature found factors that affect innovation and the impact of innovation on firm performance [12-15]. As innovation objectives are factors affect to innovation performance, the objective of innovation should be considered when analyzing innovation outcome $[5,6]$. The aims of innovation are different by firms depending on their innovation patterns and environment, and the importance of innovation objectives could be various based on firms' status, ownership, resources for innovation, and size [16-18].

Most of the literature focused on the objectives of innovation found that the economic advantage is the major purpose of firms pursuing innovation. Fu et al. (2014) mentioned that the most important objective of innovation is the improvement of quality and range of goods and services, and Naidoo (2010) said that improvement of performance by developing new or modified products and processes is the main reason for innovation $[7,19]$. Other studies found that enhancing firm level competitiveness is the major purpose of innovation for SMEs, as product innovation is to change product design and shapes to meet customer demands and process innovation is to reduce cost and improve the quality $[20,21]$. Firms perform innovation for other reasons as well, to gain access to non-tradable assets, to shorten response time, to improve innovation skills, to enhance knowledge sharing, and others $[5,22,23]$.

Though the original purpose of innovation mostly focused on economic benefits, the aim of innovation nowadays has broadened to include societal impact as well, such as climate and health challenges [9]. Firms engage in innovation for sustainability-related objectives, such as the reduction of material and energy costs and the improvement of working conditions on health and safety [7]. Sustainable innovation introduced sustainability as a major goal of innovation [8].

Though sustainability-related reasons could become the main objectives of pursuing innovation, studies mostly focused on economic objectives, while not many studies investigate into environmental and societal reasons as firms' objective of innovation. Given that performance is influenced by innovation objectives, it is essential and highly worthwhile to investigate the actual effect of sustainability-related motivations as an objective of innovation on innovation outcome $[5,6]$.

\subsection{Innovation Efficiency}

Innovation efficiency is commonly defined as "the ability to translate innovation inputs into innovation outputs", and it could be improved with less innovation inputs required for the same level 
of the outputs, or same amount of the inputs used with more output generation [10,24]. As innovation is not a linear process in which inputs automatically transform into outputs, innovation efficiency, which is a ratio of innovation outputs over inputs, should be examined [10,11]. Accordingly, diverse studies have examined the efficiency of innovation, and DEA has been widely adopted as a method to capture the efficiency of innovation, when comparing the output to its input.

The decision making units (DMUs) of studies on innovation efficiency have been diverse; from firm-level to province-level, even broader to the country-level [10,11,25-30]. Table 1 summarized recent studies of innovation efficiency.

\subsection{Sustainable Innovation}

Sustainability is essential for organizations to run their business, and diverse studies found out factors that have a potential effect on sustainable operations [31-33]. As sustainable innovation becomes an important topic in the field of innovation, the effects of sustainable innovation on firm performance has been one of the main research dimensions [34]. Because sustainability is a broad concept and encompasses not only environmental issues but also social issues, sustainable innovation has been measured in various ways. Most of the researches have focused on preventing the negative impact on environment as sustainable innovation, while several researches have extended its scope to material and energy reduction, or even to social responsibility.

Eco-innovation, which could be defined as "new products and processes that provide customer and business value but significantly decrease environmental impacts", found to be positively related to firms' performance $[35,36]$. Though eco-innovation is more important than non-eco-innovation in determining firm performance, eco-innovators face greater difficulty in attracting venture capital for development compare to other innovators [37,38].

Green innovation, which is defined as "hardware or software innovation that is related to green products or processes, including the innovation in technologies that are involved in energy-saving, pollution-prevention, waste recycling, green product designs, or corporate environmental management", has been studied as well [39]. Diverse studies found out the positive effect of green innovation on firm performance, such as material or energy reduction and environmental improvement [39-44]. In a similar vein, environmental marketing is found to affect positively to firms' capabilities $[45,46]$. Walsh and Beatty $(2007)$ found that social and environmental responsibility is positively correlated to customer satisfaction and trust in the service industry [47]. Testa et al. (2011) showed that strict environmental regulation stimulates firms to increase investments in technological equipment and innovative products, which leads to higher business performance [48].

Eco, green, and environmental innovation, as mentioned above, show minor differences with sustainable innovation [36]. Though most of the studies found out the positive effect of such sustainable innovation, Baker and Sinkula (2005) showed that environmental marketing does not directly related to the market share [45]. Moreover, Ghisetti and Rennings (2014) figured out that innovations that are related to externality reduction, such as reducing air, water, noise pollution, and harmful materials, has a negative effect on firms' competitiveness [49].

To sum up, though the effect of sustainable innovation on firm performance has been investigated, the effect of sustainability as motivation of innovation is still unanswered. More importantly, while literature on innovation keep emphasize on the importance of measuring the efficiency of it considering input and output together, studies on sustainable innovation is yet to consider the overall efficiency, but rather the performance itself $[10,11]$. To fill the gap between the effect of sustainability as an objective of innovation and its innovation performance, and to bridge the hole between the outcome of sustainable innovation and its efficiency, we unravel the linkage of sustainability as innovation objective and innovation efficiency. 
Table 1. Studies of innovation efficiency.

\begin{tabular}{|c|c|c|c|c|c|}
\hline Sources & Method & DMUs & & Input Factor & Output Factor \\
\hline Wang et al. (2016) [29] & DEA & 38 Chinese new energy enterprises & $\begin{array}{l}(1) \\
\text { (2) } \\
\text { (3) }\end{array}$ & $\begin{array}{l}\text { Fixed assets } \\
\text { Staff wages } \\
\text { R\&D costs }\end{array}$ & $\begin{array}{ll}\text { (1) } & \text { Total profits } \\
\text { (2) } & \text { Market value }\end{array}$ \\
\hline Cruz-Cázares et al. (2013) [26] & DEA/Malmquist index & $\begin{array}{l}415 \text { (first stage)/362 (second stage) } \\
\text { Spanish manufacturing firms }\end{array}$ & $\begin{array}{l}(1) \\
(2)\end{array}$ & $\begin{array}{l}\text { R\&D capital stock } \\
\text { High-skill staff }\end{array}$ & $\begin{array}{l}\text { (1) The number of product innovations } \\
\text { (2) The number of patents }\end{array}$ \\
\hline Guan et al. (2006) [28] & DEA & 182 Chinese industrial innovative firms & $\begin{array}{l}(1) \\
(2) \\
(3) \\
(4) \\
(5)\end{array}$ & $\begin{array}{l}\text { Learning } \\
\text { R\&D } \\
\text { Manufacturing } \\
\text { Marketing } \\
\text { Resource }\end{array}$ & $\begin{array}{l}\text { (1) } \text { Market share } \\
\text { (2) Sales growth } \\
\text { (3) Export rate } \\
\text { (4) Profit growth } \\
\text { (5) Productivity } \\
\text { (6) New product rate }\end{array}$ \\
\hline Chen and Guan (2012) [25] & DEA & 30 Chinese province-level regions & $\begin{array}{l}(1) \\
(2) \\
(3) \\
(4) \\
(5) \\
(6)\end{array}$ & $\begin{array}{l}\text { Expenditure on science and technology } \\
\text { Number of science and technology personnel } \\
\text { Foreign direct investment } \\
\text { Expenditure on the import of technology } \\
\text { Expenditure on the purchase of domestic technology } \\
\text { Value of contractual inflows in domestic } \\
\text { technical markets }\end{array}$ & $\begin{array}{l}\text { (1) Gross domestic products } \\
\text { (2) Sale of new products } \\
\text { (3) Value of exports } \\
\text { (4) Annual income in urban residents per capita }\end{array}$ \\
\hline Zhong et al. (2011) [30] & DEA & 30 Chinese province-level regions & $\begin{array}{l}(1) \\
(2)\end{array}$ & $\begin{array}{l}\text { R\&D expenditure } \\
\text { Full-time equivalent of R\&D personnel }\end{array}$ & $\begin{array}{l}\text { (1) Patent applications } \\
\text { (2) Sales revenue of new products } \\
\text { (3) Profit of primary business }\end{array}$ \\
\hline Guan and Chen (2010) [27] & DEA & 26 Chinese province-level regions & $\begin{array}{l}\text { (1) } \\
\text { (2) } \\
\text { (3) }\end{array}$ & $\begin{array}{l}\text { Internal expenditure of R\&D funding } \\
\text { Full-time equivalence of scientists and technologists } \\
\text { on R\&D activities } \\
\text { Accumulated patents stock }\end{array}$ & $\begin{array}{l}\text { (1) The value added taxes } \\
\text { (2) The value added profits } \\
\text { (3) The export value of new products } \\
\text { (4) The sale revenue of new products }\end{array}$ \\
\hline Guan and Chen (2012) [11] & DEA & 22 Countries & $\begin{array}{l}\text { (1) } \\
\text { (2) } \\
\text { (3) }\end{array}$ & $\begin{array}{l}\text { Number of full-time equivalent scientists } \\
\text { and engineers } \\
\text { Incremental R\&D expenditure } \\
\text { Prior accumulated knowledge stock breeding } \\
\text { upstream knowledge production }\end{array}$ & $\begin{array}{l}\text { (1) Added value of industries } \\
\text { (2) Export of new products in high-tech industries }\end{array}$ \\
\hline Hollanders and Celikel-Esser (2007) [10] & DEA & 35 Countries & $\begin{array}{l}(1) \\
(2) \\
(3)\end{array}$ & $\begin{array}{l}\text { Innovation drivers } \\
\text { Knowledge creation } \\
\text { Innovation \& entrepreneurship }\end{array}$ & $\begin{array}{ll}\text { (1) } & \text { Applications } \\
\text { (2) } & \text { Intellectual property }\end{array}$ \\
\hline
\end{tabular}




\section{Methodology and Model}

The method that we use is twofold. First, we calculate the innovation efficiency of each firm with the Data Envelopment analysis (DEA) method. Then, we investigate the effect of sustainable innovation objectives on the innovation efficiency, while considering material and energy reduction (MERE), environment improvement (ENIM), and safety improvement (SAIM).

\subsection{Data Envelopment Analysis and Tobit Regression}

The deterministic parametric (DFA), the stochastic frontier (SFA), and the data envelopment analysis (DEA) are useful methods to measure efficiency. DFA, which is modified from the method of Schmidt and Sikles (1984) and suggested by Berger (1993), is not appropriate for the short time period because it tends to offset the random error [50,51]. SFA, which is suggested by Aigner et al. (1977), moreover, has its weakness that it requires specific function form and distribution [52]. Therefore, this study utilized DEA method instead of DFA and SFA, as the data that we used is a single year data and does not necessarily assume a specific productivity function form.

DEA is a nonparametric method used to measure relative efficiency, based on linear programming. DEA does not assume any forms of specific function unlike other methods such as linear regression but rather set an evaluation standard with efficiency frontier, and measure relative efficiency by using empirical input and output factors. Charnes et al. (1978) and Banker et al. (1984) mentioned a basic assumption of DEA, which is that the matrix elements composed by pair of the input factors of decision making units (DMUs) are comprised by plural input factors [53,54]. Therefore, the innovation efficiency in this study could be an indicator of how sufficiently firms succeeded in innovation by comparing the input and output for innovation. Studies on innovation used DEA to measure innovation efficiency, as mentioned in Section 2, DEA is determined to be an appropriate method to measure innovation efficiency [10,11,25-30].

In the first step, we use the slack based DEA model (SBM DEA), which has emerged to overcome limitations that the original radial model could not measure efficiency precisely and it also could not distinguish efficiency when there exist many DMUs having efficiency score as 1. SBM DEA is a non-radial model and it has an advantage that it reflects not only radial factors of input and output factors, but also non-radial slacks [55].

In the second step, we set three sustainability-related objectives of innovation as environmental variables and analyze the potential effect of them on innovation efficiency, as measured from the first step. Efficiency scores of DEA, except for the super efficiency model, always have its value between 0 and 1 . Therefore, estimation of regression coefficient by ordinary least squares (OLS) has a problem of its regression coefficient being inconsistent and biased estimates. Therefore, we perform tobit regression analysis to measure the effects of environmental variables on innovation efficiency, following studies that used tobit regression when the dependent variable was set as efficiency score $[56,57]$. In this study, we use slack based DEA model and tobit regression analysis to find out the effect of sustainability consideration factors on innovation efficiency.

\subsection{Data and Measurement}

As the objective of this study is to verify the effect of sustainability as an objective of innovation on innovation efficiency, this research utilized the data on the Korean manufacturing industry from the 2016 Korean Innovation Survey (KIS), which was conducted by the Science and Technology Policy Institute (STEPI), Korea. As the data contains overall innovation data, including the objectives of innovation, resources used for innovation (input of innovation), and innovation performance (output of innovation), KIS data is believed to be appropriate for this research. Although the KIS data survey encompasses overall innovation status among Korean firms, it does not provide the full range of data that is required to perform this study. Moreover, firms that have 0 value as their output factors, which are patent application and innovation sales, imply no meaning when comparing the efficiency, 
because all data with output factor as 0 would have 0 as their efficiency score regardless of how high or low the input factors are. Therefore, the data for 441 samples out of 4000 firms were used as DMUs and were utilized for the statistical analysis, after excluding incomplete or unrealistic data and data with output as 0 .

Since KIS data asked firms to answer the number of regular employees and the percentage of R\&D employees out of regular employees, we multiplied the number of regular employees by the percentage of $R \& D$ employees divided by 100 , in order to measure the number of $R \& D$ employees. To measure R\&D expense, we captured the total expense for innovation. The patent application is measured as the number of patent application. To capture innovation sales, we multiplied the total sales by the percentage of innovative products sales out of total sales, divided by 100 .

We adopt sustainability consideration factors as environmental variables to analyze the potential effect of them on innovation efficiency. Three sustainability consideration factors, MERE (material and energy reduction), ENIM (environment improvement), and SAIM (safety improvement) are measured as the extent to how important such factors are perceived by innovation managers as objective for innovation. The higher the sustainability consideration factor score, the more importantly managers perceived as an objective for innovation (0: no importance; 1: low importance; 2: medium importance; 3: high importance). The detailed explanation for input/output and sustainability consideration factors is explained as Table 2 below.

\subsection{Model}

The research model of this study is as Figure 1.

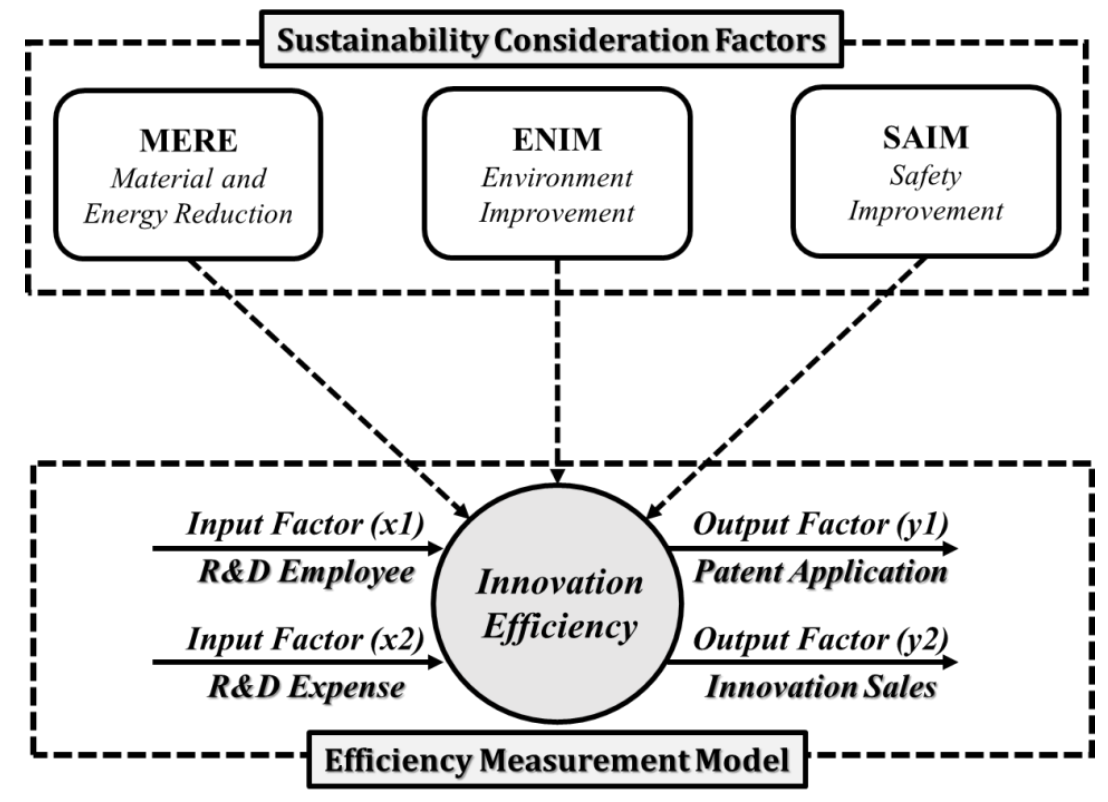

Figure 1. Research model.

First, we consider the input and output factors of previous literature to measure innovation efficiency. To analyze innovation efficiency precisely, we adopted the number of R\&D employee and R\&D expense as two input factors [11,25-30]. Similarly, patent application and innovation sales are set as output factors $[10,25-27,30]$.

The descriptive statistics is shown as in Table 3. 
Table 2. Factors and related questionnaire in Korean Innovation Survey (KIS) data.

\begin{tabular}{|c|c|c|}
\hline & Factors & Questionnaire in KIS Data \\
\hline \multirow{3}{*}{ Input } & \multirow[b]{2}{*}{ R\&D employee } & The number of regular employee \\
\hline & & $\begin{array}{l}\text { The percentage of the number of R\&D employee out of the } \\
\text { number of regular employee }\end{array}$ \\
\hline & $R \& D$ expense & Total innovation cost \\
\hline \multirow{3}{*}{ Output } & Patent application & The number of patent application \\
\hline & \multirow{2}{*}{ Innovation sales } & Total sales \\
\hline & & The percentage of innovative product sales out of total sales \\
\hline \multirow{3}{*}{ Environmental } & Material and energy reduction & $\begin{array}{l}\text { How important is the following objective to perform } \\
\text { innovation?-" "material and energy cost reduction" }\end{array}$ \\
\hline & Environment improvement & $\begin{array}{l}\text { How important is the following objective to perform } \\
\text { innovation?- "improvement of harmful influence } \\
\text { on environment" }\end{array}$ \\
\hline & Safety improvement & $\begin{array}{l}\text { How important is the following objective to perform } \\
\text { innovation?- "improvement of working environment or } \\
\text { workplace safety" }\end{array}$ \\
\hline
\end{tabular}

Table 3. Descriptive statistics.

\begin{tabular}{cccccc}
\hline Factors & Minimum & Maximum & Average & St.dev & Median \\
\hline R\&D employee & 0 & 134.4 & 10.30 & 13.20 & 6 \\
R\&D expense & 20 & 3845 & 621.74 & 782.79 & 300 \\
Patent application & 1 & 130 & 4.19 & 8.44 & 2 \\
Innovation sales & 0 & $14,000,000$ & $1,083,976.10$ & $1,803,877.57$ & 367,950 \\
Material and energy reduction & 0 & 3 & 2.24 & 0.80 & 2 \\
Environment improvement & 0 & 3 & 2.13 & 0.84 & 2 \\
Safety improvement & 0 & 3 & 2.22 & 0.79 & 2 \\
\hline
\end{tabular}

The details of data set, such as the number of firms, average of all of the input variables, output variables, and sustainability-related variables, are presented by industry types, as in Table 4 . The industry type is categorized by Korean standard industrial classification (KSIC). 
Table 4. Details of data categorized by industry types.

\begin{tabular}{|c|c|c|c|c|c|c|c|c|}
\hline Industry Type & No. of Firms & $\begin{array}{l}\text { Ave. R\&D } \\
\text { Employee }\end{array}$ & $\begin{array}{c}\text { Ave. R\&D } \\
\text { Expense }\end{array}$ & $\begin{array}{l}\text { Ave. Patent } \\
\text { Application }\end{array}$ & $\begin{array}{l}\text { Ave. Innovation } \\
\text { Sales }\end{array}$ & $\begin{array}{l}\text { Ave. Material and } \\
\text { Energy Reduction }\end{array}$ & $\begin{array}{l}\text { Ave. Environment } \\
\text { Improvement }\end{array}$ & $\begin{array}{l}\text { Ave. Safety } \\
\text { Improvement }\end{array}$ \\
\hline Food products & 9 & 11.08 & 566.67 & 2.11 & $623,555.56$ & 2.33 & 2.33 & 2.22 \\
\hline Beverages & 1 & 30.00 & 1700.00 & 1.00 & $7,980,000.00$ & 2.00 & 1.00 & 2.00 \\
\hline Textiles; except for apparel & 6 & 6.75 & 585.83 & 2.83 & $2,798,538.33$ & 1.83 & 1.17 & 1.50 \\
\hline Wearing apparel, clothing accessories and fur articles & 1 & 0.39 & 50.00 & 3.00 & $325,000.00$ & 3.00 & 3.00 & 3.00 \\
\hline Tanning and dressing of leather, luggage and footwear & 1 & 0.21 & 20.00 & 2.00 & $162,000.00$ & 2.00 & 0.00 & 2.00 \\
\hline Wood and cork; except for furniture & 2 & 2.49 & 109.50 & 4.00 & $112,965.00$ & 3.00 & 2.50 & 2.50 \\
\hline Pulp, paper and paper products & 3 & 5.22 & 252.67 & 5.33 & $346,936.67$ & 2.00 & 1.67 & 2.00 \\
\hline Printing and reproduction of recorded media & 2 & 16.20 & 400.00 & 3.50 & $2,532,595.00$ & 2.00 & 2.00 & 2.00 \\
\hline $\begin{array}{l}\text { Chemicals and chemical products; except for pharm aceuticals and } \\
\text { medicinal chemicals }\end{array}$ & 15 & 9.52 & 843.33 & 6.87 & $745,283.67$ & 2.20 & 2.20 & 2.27 \\
\hline Pharm aceuticals, medicinal chemicals and botanical products & 7 & 23.03 & 1146.86 & 3.29 & $1,635,902.86$ & 2.14 & 2.14 & 1.86 \\
\hline Rubber and plastic products & 58 & 7.72 & 428.45 & 3.16 & $1,362,250.69$ & 2.41 & 2.48 & 2.59 \\
\hline Other non-metallic mineral products & 8 & 4.45 & 543.63 & 3.75 & $1,416,505.75$ & 2.25 & 1.88 & 1.88 \\
\hline Basic metal products & 7 & 6.35 & 315.57 & 2.00 & $3,164,458.57$ & 2.00 & 2.00 & 2.29 \\
\hline Fabricated metal products; except for machinery and furniture & 27 & 7.72 & 3347.07 & 3.74 & $1,953,212.96$ & 1.85 & 1.41 & 1.78 \\
\hline $\begin{array}{l}\text { Electronic components, computer, radio, television and communication } \\
\text { equipment and apparatuses }\end{array}$ & 45 & 15.61 & 867.60 & 6.31 & $1,091,366.11$ & 1.78 & 1.71 & 1.69 \\
\hline Medical, precision and optical instruments, watches and clocks & 38 & 15.02 & 302.37 & 4.13 & $879,981.05$ & 2.26 & 2.08 & 2.16 \\
\hline Electrical equipment & 40 & 11.24 & 579.38 & 3.28 & $993,990.88$ & 2.18 & 2.08 & 2.25 \\
\hline Other machinery and equipment & 133 & 8.30 & 621.57 & 4.21 & $488,040.50$ & 2.50 & 2.42 & 2.47 \\
\hline Motor vehicles, trailers and semitrailers & 28 & 12.92 & 1352.04 & 3.96 & $1,949,646.43$ & 2.00 & 1.96 & 2.04 \\
\hline Other transport equipment & 4 & 15.23 & 1102.50 & 12.50 & $2,285,910.00$ & 2.00 & 1.75 & 1.75 \\
\hline Furniture & 3 & 5.24 & 608.67 & 6.67 & $650,718.00$ & 1.67 & 1.33 & 1.67 \\
\hline Other manufacturing & 3 & $\begin{array}{l}3.67 \\
4.60\end{array}$ & 150.00 & 3.00 & $21,503.33$ & 2.67 & 2.00 & 2.00 \\
\hline
\end{tabular}




\section{Results}

As only 11 DMUs out of 441 are found to have 1 as the efficiency score, which is the highest, the slack based model that is used in this study is believed to distinguish the difference of efficiency among DMUs well. To perform further analysis, we categorized DMUs into three groups based on their efficiency and assigned 147 DMUs in each category. The average score of each group are shown as Table 5 below.

Table 5. Average of three decision making units (DMU) groups categorized by efficiency.

\begin{tabular}{cccc}
\hline \multirow{2}{*}{ Group } & \multicolumn{3}{c}{ Average Score } \\
\cline { 2 - 4 } & MERE & ENIM & SAIM \\
\hline High efficiency & 2.2789 & 2.1837 & 2.3061 \\
Medium efficiency & 2.1905 & 2.0204 & 2.1633 \\
Low efficiency & 2.2249 & 2.1769 & 2.1837 \\
\hline
\end{tabular}

Comparing the average score of MERE, ENIM, and SAIM among three groups, we found a polarization between the low and medium efficiency level groups; that is, managers at low efficiency firms tend to perceive sustainability consideration factors more importantly than those of the medium efficiency firms. Though it is desirable to calculate the average of efficiency score by the extent to how importantly managers perceive sustainability consideration factors for further analysis, the limitation that DEA is a nonparametric methodology makes the calculation of average among efficiency score unable to be statistically significant [58]. Instead, we performed tobit regression analysis to verify potential effect of sustainability consideration factors on innovation efficiency. The regression result is presented as Table 6.

Table 6. Tobit regression for sustainability consideration factors.

\begin{tabular}{ccc}
\hline & \multicolumn{2}{c}{ Dependent Variable: Innovation Efficiency } \\
\cline { 2 - 3 } & Coefficient & Standard Error \\
\hline (Intercept) & $0.134^{* * *}$ & 0.030 \\
MERE & 0.003 & 0.019 \\
ENIM & $-0.044^{* *}$ & 0.021 \\
SAIM & $0.054^{* *}$ & 0.022 \\
Log-sigma & $-1.605^{* * *}$ & 0.034 \\
\hline \multicolumn{3}{c}{}
\end{tabular}

While we could not verify the effect of perceived importance of MERE by managers on innovation efficiency, the effect of perceived importance of ENIM and SAIM turned out to influence on innovation efficiency. First, the perceived importance of environment improvement by managers negatively affect to innovation performance. It is quite surprising because most of the previous literature pointed out that innovation improving environment leads to higher firm performance [37,39-43]. Given that previous literature considered the output only, however, the result of this study does not counter the literature, but rather point to the possibility that the input that is required to perform environmental innovation is much higher than the actual output transformed from it. As firms increase investments in technological equipment and innovative products to meet environmental standard, the input required from environmental innovators is expected to be much higher than others [48]. Such input sometimes could become even enormous, as venture capital is much difficult to attract for environmental innovators [38]. In the same context, the innovation for environmental improvement is found to require an increase in input for innovation, which leads to low innovation efficiency.

Second, innovation for safety of workers or workplace environment positively affects innovation performance. The result supports previous literature which pointed out that lack of ergonomics 
would decrease worker productivity consequently, safer and healthier workplace environment help firms achieve higher level of quality and productivity, and workplace environment increase firm performance, such as an increase in productivity and work quality, while a decrease in lost time at work [59-61]. Innovation for safety of workers and/or workplace environment increases innovation performance highly, as in previous studies, which leads to higher innovation efficiency.

\section{Conclusions}

Up until now, not only the effect of sustainability as an objective of innovation on innovation performance, but also the relationship between the sustainable innovation and innovation efficiency has been vague. By analyzing the linkage between the effect of sustainability as an objective of innovation and innovation efficiency, we suggest several implications.

First, most of the researches pointed out the positive effect of environmental innovation on innovation performance, which might lead managers at firms to pursue such innovation blindly. However, the result of this study found that the amount increased in input could overweigh when compared to the output when performing innovation for environmental reasons. Therefore, managers should compare the input that is required for environmental innovation and the expected outcome carefully before undertaking such innovation.

Second, the innovation for safety of workers and/or workplace environment is found to have positive effect on innovation efficiency. It means that the advantage of innovation for the improvement of safety of workers and/or workplace environment outweighs the cost; firms would have higher innovation performance with such innovation if they were open to further improvement of workers' safety and workplace environment.

Though this study fills the gap of literatures and suggest practical implications, a few limitations could be pointed. First, as mentioned at the introduction, innovation is a continuous and cumulative process but not a single event. That is, the resources that are invested for innovation in this period do not necessarily transformed into the output in the same or the very next period, but rather turn into the actual performance gradually. Though it is almost impossible to capture the amount of output that is contributed by specific input, efficiency considering time series is expected to measure it more precisely, and we leave it to the future research.

Second, the sustainability-related objective of innovation is measured by three variables only: MERE, ENIM, and SAIM. This is because of the limitation of KIS data as we use it as a secondary data; future research is expected to have an advantage to encompass other sustainability-related objectives as well by conducting survey to managers at firms. Moreover, input and output variables other than the ones that are covered in this paper could provide a more realistic relationship between sustainability as objective of innovation and innovation efficiency.

Author Contributions: J.S. and C.K. conceived and designed the experiments. And the experiment was performed by all related authors. The paper is written by J.S. and C.K. Finally, H.Y. revised the manuscript and all authors read and approved the final manuscript.

Funding: Hongsuk Yang's research was supported by the Institute of Management Research at Seoul National University.

Conflicts of Interest: The authors declare no conflict of interest.

\section{References}

1. Lundvall, B.A. National Innovation System: Towards a Theory of Innovation and Interactive Learning; Pinter: London, UK, 1992.

2. Johannessen, J.A.; Olsen, B.; Olaisen, J. Aspects of innovation theory based on knowledge-management. Int. J. Inf. Manag. 1999, 19, 121-139. [CrossRef]

3. Korsnes, M.S. The Growth of a Green Industry: Wind Turbines and Innovation in China; University of Oslo: Blindern, Norway, 2012. 
4. Eccles, R.G.; Perkins, K.M.; Serafeim, G. How to become a sustainable company. MIT Sloan Manag. Rev. 2012, $53,43-50$.

5. Meroño-Cerdan, A.L.; López-Nicolas, C. Understanding the drivers of organizational innovations. Serv. Ind. J. 2013, 33, 1312-1325. [CrossRef]

6. Wang, T.; Chien, S. Forecasting innovation performance via neural networks-A case of Taiwanese manufacturing industry. Technovation 2006, 26, 635-643. [CrossRef]

7. Fu, X.; Zanello, G.; Essegbey, G.O.; Hou, J.; Mohnen, P. Innovation in Low Income Countries: A Survey Report. Growth Research Programme. 2014. Available online: https://assets.publishing.service.gov.uk/media/ 57a089abed915d3cfd00038a/61071_DILIC_Report_2.pdf (accessed on 12 June 2018).

8. Schultze, J.; Schröder, A.; Hölsgens, R. Report on the Pilot Application of CASI-F for Assessing Sustainable Social Innovation. 2016. Available online: http:/ / www.sfs.tu-dortmund.de/cms/en/publications/details / index.php?id=1729 (accessed on 17 May 2018).

9. Wintjes, R. Systems and Modes of ICT Innovation; JRC Science for Policy Report; European Commission-Joint Research Centre: Bruselas, Belgium, 2016.

10. Hollanders, H.; Celikel-Esser, F. Measuring Innovation Efficiency. Available online: http:/ /www.pedz.unimannheim.de/daten/edz-h/gdb/07/eis_2007_Innovation_efficiency.pdf (accessed on 12 June 2018).

11. Guan, J.; Chen, K. Modeling the relative efficiency of national innovation systems. Res. Policy 2012, 41, 102-115. [CrossRef]

12. Ozkan-Canbolat, E.; Beraha, A. Configuration and innovation related network topology. J. Innov. Knowl. 2016, 1, 91-98. [CrossRef]

13. Zulu-Chisanga, S.; Boso, N.; Adeola, O.; Oghazi, P. Investigating the path from firm innovativeness to financial performance: The roles of new product success, market responsiveness, and environment turbulence. J. Small Bus. Strategy 2016, 26, 51-67.

14. Allal-Chérif, O.; Bidan, M. Collaborative open training with serious games: Relations, culture, knowledge, innovation, and desire. J. Innov. Knowl. 2017, 2, 31-38. [CrossRef]

15. Dudukalov, E.V.; Rodionova, N.D.; Sivakova, Y.E.; Vyugova, E.; Cheryomushkina, I.V.; Popkova, E.G. Global innovational networks: Sense and role in development of global economy. Contemp. Econ. 2016, 10, $299-310$. [CrossRef]

16. Guan, J.; Yam, R.; Tang, E.; Lau, A. Innovation strategy and performance during economic transition: Evidences in Beijing, China. Res. Policy 2009, 38, 802-812. [CrossRef]

17. Leiponen, S.; Helfat, C.E. Innovation objectives, knowledge sources, and he benefits of breadth. Strateg. Manag. J. 2010, 31, 224-236. [CrossRef]

18. Yang, H.; Hsiao, S. Mechanisms of developing innovative IT-enabled services: A case study of Taiwanese healthcare service. Technovation 2009, 29,327-337. [CrossRef]

19. Naidoo, V. Firm survival through a crisis: The influence of market orientation, marketing innovation and business strategy. Ind. Mark. Manag. 2010, 39, 1311-1320. [CrossRef]

20. Bala-Subrahmanya, M.H. Technological Innovation in Indian SMEs: Need, Status and Policy Imperatives. Curr. Opin. Creat. Innov. Entrep. 2012, 1, 7-12.

21. Olomu, M.; Akinwale, Y.; Adepoju, A. Harnessing technological and nontechnological innovations for SMEs profitability in the Nigerian Manufacturing Sector. Am. J. Bus. Econ. Manag. 2016, 4, 75-88.

22. Albers, J.A.; Brewer, S. Knowledge management and the innovation process: The eco-innovation model. J. Knowl. Manag. Pract. 2003, 4, 1-6.

23. Kotabe, M.; Murray, J. Linking product and process innovations and modes of international sourcing in global competition: A case of foreign multinational firms. J. Int. Bus. Stud. 1990, 21, 383-408. [CrossRef]

24. Liu, Z.; Chen, X.; Chu, J.; Zhu, Q. Industrial development environment and innovation efficiency of high-tech industry: Analysis based on the framework of innovation systems. Technol. Anal. Strateg. 2018, 30, 434-446. [CrossRef]

25. Chen, K.; Guan, J. Measuring the efficiency of China's regional innovation systems: Application of network data envelopment analysis (DEA). Reg. Stud. 2012, 46, 355-377. [CrossRef]

26. Cruz-Cázares, C.; Bayona-Sáez, C.; García-Marco, T. You can't manage right what you can't measure well: Technological innovation efficiency. Res. Policy 2013, 42, 1239-1250. [CrossRef]

27. Guan, J.; Chen, K. Measuring the innovation production process: A cross-region empirical study of China's high-tech innovations. Technovation 2010, 30, 348-358. [CrossRef] 
28. Guan, J.C.; Yam, R.C.; Mok, C.K.; Ma, N. A study of the relationship between competitiveness and technological innovation capability based on DEA models. Eur. J. Oper. Res. 2006, 170, 971-986. [CrossRef]

29. Wang, Q.; Hang, Y.; Sun, L.; Zhao, Z. Two-stage innovation efficiency of new energy enterprises in China: A non-radial DEA approach. Technol. Forecast. Soc. 2016, 112, 254-261. [CrossRef]

30. Zhong, W.; Yuan, W.; Li, S.X.; Huang, Z. The performance evaluation of regional R\&D investments in China: An application of DEA based on the first official China economic census data. Omega 2011, 39, 447-455. [CrossRef]

31. Wakil, A.A. When Gambling is Not Winning: Exploring Optimality of VIX Trading under the Expected Utility Theory. J. Bus. Account. Financ. Perspect. 2018. [CrossRef]

32. Cuomo, M.T.; Tortora, D.; Mazzucchelli, A.; Festa, G.; Di Gregorio, A.; Metallo, G. Impacts of Code of ethics on financial performance in the Italian listed companies of bank sector. J. Bus. Account. Financ. Perspect. 2018, in press. [CrossRef]

33. Gajdová, D.; Majdúchová, H. Financial Sustainability Criteria and their testing in the conditions of the Slovak Non-Profit Sector. Contemp. Econ. 2018, 12, 33-56. [CrossRef]

34. De Medeiros, J.F.; Ribeiro, J.L.D.; Cortimiglia, M.N. Success factors for environmentally sustainable product innovation: A systematic literature review. J. Clean. Prod. 2014, 65, 76-86. [CrossRef]

35. Fussler, C.; James, P. Driving Eco-Innovation: A Breakthrough Discipline for Innovation and Sustainability, Financial Times Management; Pitman Publishing: London, UK, 1996.

36. Schiederig, T.; Tietze, F.; Herstatt, C. Green innovation in technology and innovation management-An exploratory literature review. $R$ D Manag. 2012, 42, 180-192. [CrossRef]

37. Doran, J.; Ryan, G. Regulation and firm perception, eco-innovation and firm performance. Eur. J. Innov. Manag. 2012, 15, 421-441. [CrossRef]

38. Halila, F.; Rundquist, J. The development and market success of eco-innovations: A comparative study of eco-innovations and "other" innovations in Sweden. Eur. J. Innov. Manag. 2011, 14, 278-302. [CrossRef]

39. Chen, Y.S.; Lai, S.B.; Wen, C.T. The influence of green innovation performance on corporate advantage in Taiwan. J. Bus. Ethics 2006, 67, 331-339. [CrossRef]

40. Chen, Y.S. The drivers of green brand equity: Green brand image, green satisfaction, and green trust. J. Bus. Ethics 2010, 93, 307-319. [CrossRef]

41. Chen, Y.S.; Chang, C.H. The determinants of green product development performance: Green dynamic capabilities, green transformational leadership, and green creativity. J. Bus. Ethics 2013, 116, 107-119. [CrossRef]

42. Lin, R.J.; Tan, K.H.; Geng, Y. Market demand, green product innovation, and firm performance: Evidence from Vietnam motorcycle industry. J. Clean. Prod. 2013, 40, 101-107. [CrossRef]

43. Peng, Y.S.; Lin, S.S. Local responsiveness pressure, subsidiary resources, green management adoption and subsidiary's performance: Evidence from Taiwanese manufactures. J. Bus. Ethics 2008, 79, 199-212. [CrossRef]

44. Rekik, L.; Bergeron, F. Green Practice Motivators and Performance in SMEs: A Qualitative Comparative Analysis. J. Small Bus. Strategy 2017, 27, 1-17.

45. Baker, W.E.; Sinkula, J.M. Environmental marketing strategy and firm performance: Effects on new product performance and market share. J. Acad. Mark. Sci. 2005, 33, 461-475. [CrossRef]

46. Fraj-Andrés, E.; Martinez-Salinas, E.; Matute-Vallejo, J. A multidimensional approach to the influence of environmental marketing and orientation on the firm's organizational performance. J. Bus. Ethics 2009, 88, 263-286. [CrossRef]

47. Walsh, G.; Beatty, S.E. Customer-based corporate reputation of a service firm: Scale development and validation. J. Acad. Mark. Sci. 2007, 35, 127-143. [CrossRef]

48. Testa, F.; Iraldo, F.; Frey, M. The effect of environmental regulation on firms' competitive performance: The case of the building \& construction sector in some EU regions. J. Environ. Manag. 2011, 92, 2136-2144. [CrossRef]

49. Ghisetti, C.; Rennings, K. Environmental innovations and profitability: How does it pay to be green? An empirical analysis on the German innovation survey. J. Clean. Prod. 2014, 75, 106-117. [CrossRef]

50. Berger, A.N. "Distribution-free" estimates of efficiency in the US banking industry and tests of the standard distributional assumptions. J. Prod. Anal. 1993, 4, 261-292. [CrossRef]

51. Schmidt, P.; Sickles, R.C. Production frontiers and panel data. J. Bus. Econ. Stat. 1984, 2, 367-374. [CrossRef] 
52. Aigner, D.; Lovell, C.K.; Schmidt, P. Formulation and estimation of stochastic frontier production function models. J. Econom. 1977, 6, 21-37. [CrossRef]

53. Banker, R.D.; Charnes, A.; Cooper, W.W. Some models for estimating technical and scale inefficiencies in data envelopment analysis. Manag. Sci. 1984, 30, 1078-1092. [CrossRef]

54. Charnes, A.; Cooper, W.W.; Rhodes, E. Measuring the efficiency of decision making units. Eur. J. Oper. Res. 1978, 2, 429-444. [CrossRef]

55. Tone, K. A slacks-based measure of efficiency in data envelopment analysis. Eur. J. Oper. Res. 2001, 130, 498-509. [CrossRef]

56. Honma, S.; Hu, J.L. Analyzing Japanese hotel efficiency. Tour. Hosp. Res. 2012, 12, 155-167. [CrossRef]

57. Huang, Y.; Mesak, H.I.; Hsu, M.K.; Qu, H. Dynamic efficiency assessment of the Chinese hotel industry. J. Bus. Res. 2012, 65, 59-67. [CrossRef]

58. Simar, L.; Wilson, P.W. Statistical inference in nonparametric frontier models: The state of the art. J. Prod. Anal. 2000, 13, 49-78. [CrossRef]

59. Fernandez, J.E. Ergonomics in the workplace. Facilities 1995, 13, 20-27. [CrossRef]

60. Shikdar, A.A.; Sawaqed, N.M. Worker productivity, and occupational health and safety issues in selected industries. Comput. Ind. Eng. 2003, 45, 563-572. [CrossRef]

61. Warrack, B.J.; Sinha, M.N. Integrating safety and quality: Building to achieve excellence in the workplace. Total Qual. Manag. 1999, 10, 779-785. [CrossRef]

(C) 2018 by the authors. Licensee MDPI, Basel, Switzerland. This article is an open access article distributed under the terms and conditions of the Creative Commons Attribution (CC BY) license (http://creativecommons.org/licenses/by/4.0/). 